\title{
Optimizing the income of a crewing company in Ukraine
}

\author{
Larysa Ivashko $^{1, *}$, Yuliya Zhuravlova $^{2}$, and Tetiana Zhuravlova $^{3}$ \\ ${ }^{1}$ Odessa I. I. Mechnikov National University, Department of Economic Cybernetics and Information Technologies, Odessa, Ukraine \\ ${ }^{2}$ Odessa National Economic University, Department of General Economic Theory and Economic Policy, Odessa, Ukraine \\ ${ }^{3}$ Odessa I. I. Mechnikov National University, Department of Finance, Banking and Insurance, Odessa, Ukraine
}

\begin{abstract}
The article analyzes the status, trends and prospects of the development of the world labor market in the field of the maritime fleet, which makes it possible to determine that for this particular segment, characterized by stable dynamic development in the presence of significant reserves. The theoretical and practical aspects of formation and development of the market of crewing services in Ukraine are also covered. The paper considers such an important task as the selection of the optimal crew for ships' shipowners in order to maximize the income of the crewing company. The economic-mathematical model of optimization of the process of selection of crews of ships was constructed. In this case, the crewing company, which has completed the work on selecting the optimal crew, receives income as a percentage of the remuneration chosen through the model of the crew for the first month of his work. The more qualified this crew, the greater the income will receive a crewing company.
\end{abstract}

\section{Introduction}

Ukraine is a maritime state and famous supplier of skilled marine personnel in the international labour market. Each year, about 69 thousand Ukrainian sailors occupy their places in the felling and technical departments of ships around the world. By level of professional training, communication skills and discipline Ukrainian sailors occupy one of the first places in the world, yielding only to Filipinos, sometimes to the Chinese. In addition, $56 \%$ of all hired frames are team members. But due to the difficult way of employment without crewing companies, a significant number of maritime workers remain unemployed. The same problem exists in shipping companies: without crewing companies is difficult to communicate to seamen with the required qualifications. Ship-owners are interested in ensuring that their ships are equipped with a highly skilled crew; seamen have an interest in getting paid jobs on board shipowners; intermediary companies see their interest in meeting the needs of both the shipowner and the seaman, as well as obtaining income from their activities. The competitiveness of shipping companies directly depends on the effective functioning of the crewing company. The professionalism of the crewing company is evaluated not only by the ability to satisfy customers' requests, but also to adjust them according to market realities and offer different ways of their satisfaction. Income derived from the recruitment of crew ships - this is one of the main indicators of the crewing agency (as well as any other company). Therefore, the most important for crewing companies is the task of optimal distribution of crew members, for which it is expedient to use economic and mathematical modeling.
Selection of crews of ships is an important part of the operations of the crewing company and an interesting task for the application of economic-mathematical modeling. Optimization of the selection of crews of ships received much less attention in the academic literature. In the works of the named scientists proposed management options for solving this problem. Therefore, the purpose of the study is to apply economic and mathematical modeling for optimal manning crewing company crews of ships sailors required qualifications to maximize its revenue.

Crewing is part of the international maritime industry. The word comes from the English crew - the team. It also deals with the complete set of commands. Unlike lowskilled professionals who are in demand in different countries, crewing deals with professionals in maritime professions. They graduated from the profile, usually higher education institutions, have long experience in managing the courts or their systems, know English, international law within their responsibilities, experience in communicating with representatives of different peoples. Of all the specialists selected for work, two thirds - the command staff. But even at the level of ordinary sailors have their own peculiarities. These are people who intend to climb up the service stages. The vast majority of them are studying and practicing on ships. Therefore, creeping is not like recruiting companies, even at recruitment agencies. Indeed, their responsibilities include not only the selection of personnel, but their testing for compliance.

Improvement in maritime education never stops. The demand for graduates of Ukrainian marine higher education institutions and institutions of secondary education is very high. Many foreign companies that have long-term programs of using Ukrainian sailors on their

\footnotetext{
*Corresponding author: ivashkolm@ukr.net
} 
ships invest significant funds in training through their own "cadet programs", providing sponsorship to marine training institutions, setting up their own training centers for the further training of seamen immediately before the voyage. Within the framework of cadet programs companies together with educational institutions conduct selection of cadets in accordance with the requirements of the company (knowledge of English, training, availability of necessary certificates), organize planning and control of the implementation of the program of floating practice on ships. In addition, the company assumes all the costs associated with the practice (flights, transfers, accommodation on board and in hotels, visa support, insurance, medical care, food, salary in accordance with the terms of an individual contract, practice on board ship). The most active in this area are the following companies in the Ukrainian market: V. Ships (Monaco), MSC Mediterranean Shipping Company (Switzerland), Bernard Schulte Shipmanagement Ltd., Peter Doehle Schiffanrts-KG, Marlow Navigation, Reederei BlueStar (Germany), Wagenberg Shipping BV, Stolt-Nielsen Transportation Group BV (Norway), Maersk Ship Management (Denmark), ASP Ship Management Group (Australia), Anglo-Eastern Ship Management (Singapore) and others [1].

Consider the types of crewing companies. Therefore, in pure creeping, if the seaman-candidate meets the requirements of the shipowner, he is taken to work and, after a certain period of time, is sent to the ship specified by him, where he begins to fulfill his labor duties. The intermediary firm for the employment assistance assisted receives a pre-defined remuneration from the client who contacted to it. This is usually either a fixed amount or a percentage of the basic salary of a sailor employed by a ship under a particular flag without the client's financial expenses incurred by the intermediary firm.

Crewing management is the more complex form of crewing that occurs on the international seamen's and maritime professionals' market. His point is that the shipowner completely transfers to the intermediary company the responsibility for resolving all issues related to the manning and management of the ship's crew. Crewing management can: Assist in arranging the necessary visas, processing sub-documents, booking air tickets, as well as informational and consulting support, conducting or organizing training or training of seamen, sending a candidate for a medical examination, engaging in the supply and sewing of work clothes, with trade unions and public organizations, etc. Also, companies can pay crew wages, draw up and maintain a timetable for changes to the crew, and more. In this case, the shipowner pays to the firm the intermediary a pre-determined fixed monthly cash sum, at the expense of which reimbursed expenses for wages, overtime pay, various additional payments and bonuses. These include: organizational expenses for servicing the crew, its delivery to the port of destination on board the ship; exchange with the Maritime Administration of the Flag State of the presented diplomas and qualification certificates; expenses on insurance of crew members from accidents; payment for crew on board; payment of working clothes and personal protective equipment, etc. The difference between the actual costs incurred by the intermediary company and the compensation paid by the shipowner as compensation for the costs incurred is the net profit of the intermediary company.

The international labor market for seamen and marine specialists has become widespread and an organizational form of mediation in employment, such as the creation of a shipowner or group of shipowners representation in those foreign countries, where mainly the recruitment of personnel of crew of ships. For example, today the company V-Ships represents 79 offices in 33 countries, 1200 ships and 25 thousand sailors, one third of who are Ukrainians. It is this part that is the merit of the office of Igor Safin (Managing Director of V-Ships), who managed to raise the level of recruitment from 700 to seven thousand Ukrainian seamen per year in 10 years [1]. Therefore, a seaman who is in need of employment, receives work directly from the hands of a potential employer. Among the hundreds of intermediary firms engaged in the employment of seamen, there are those that are created in Western Europe. These firms, as a rule, show a high organizational level.

Consequently, the elementary forms of pure creeping were transformed into new, integrated forms of service for shipowners and seamen, ranging from recruitment and training of personnel to management ship of shipowners. In this case, the shipowner loses the need to maintain expensive services engaged in the technical and commercial exploitation of ships. In addition, he receives a guaranteed source of replenishment of the staffing of crews of ships, which is characterized by stability and subject to control. The intermediary company, which owns a well-designed questionnaire for applicants for mariners, can respond quickly and flexibly to shipowner inquiries regarding the crew of ships. Currently, crewing companies and their branches are available in any port city of Ukraine: Odessa, Chornomorsk, Yuzhne, Mykolaiv, Izmail, Mariupol, Kherson and others. The number of crewing companies in the four largest supplier countries of the maritime labor force of the former USSR is as follows: Ukraine has 374 agencies in 2009, 450 in 2018; Russia-176; Latvia - 59; Lithuania - -7. Given the relatively small number of seamen in the Baltic countries and the less attractive work at sea for EU citizens, the Baltic agencies are actively recruiting sailors from Ukraine and Russia [2].

In recent years, there has been a process of active entry of large foreign companies into the Russian and especially Ukrainian market: the opening of representative offices, as well as the absorption of local companies in order to join them in the global office system. Ukraine has all the key European players in the market for crewing services, as well as a significant number of companies from the Asian region. In addition, a significant number of large shipping companies have opened their offices, which are also engaged in recruiting staff. The presence of foreign capital is increasingly felt in the Ukrainian market and slightly less in the Russian market. If in the early 2000s almost all companies were independent, then the process of entering the network of offices of international crewing agencies began to take place the so-called globalization. 
Authoritative international organizations BIMCO and ISF prepare a joint study of the labor market in the world maritime trading fleet every five years - Manpower Report. Such studies have been conducted since 1990. The latest Manpower Report was presented in May 2016 [3]. This study helps to assess the role and place of Ukrainian seamen in the world maritime labor market. In our country, such studies are not conducted, and on the question of how many Ukrainian seamen working on ships of the world navy fleet, different answers can be received at various instances. For example, in the spring of 2018, the Ministry of Infrastructure officially voiced a figure of 150 thousand. So many Ukrainian sailors, according to the ministry, today operate in the fleet [1]. Manpower Report 2016 from BIMCO and ICS calls quite different numbers. According to BIMCO and ISF, Ukraine continues to be part of a group of countries leaders in supplying seamen to the world fleet. According to the report, in Ukraine, 234,923 people are sailors, but 69,000 sailors were actually delivered to the fleet in 2015 , in addition to 39,000 officers and 30,000 ordinary [2, 4]. In essence, it is about the number of jobs occupied by Ukrainian sailors in 2015. This is the sixth place in the world after China (243.6 thousand), the Philippines (215.5 thousand), Indonesia (143.7 thousand), Russia (97 thousand), and India (86 thousand) (Table 1).

Table 1. Countries are the largest suppliers of seamen to the labor market.

\begin{tabular}{|c|c|c|c|c|c|c|}
\hline Country & $\begin{array}{c}\text { Population } \\
\text { (2015 year) }\end{array}$ & $\begin{array}{c}\text { Number of } \\
\text { seamen }\end{array}$ & $\begin{array}{c}\text { Number of } \\
\text { officers }\end{array}$ & $\begin{array}{c}\text { \%officers of the } \\
\text { country among all } \\
\text { officers }\end{array}$ & $\begin{array}{c}\text { \% officers among the } \\
\text { total number of seamen }\end{array}$ & $\begin{array}{c}\text { \% sailors to } \\
\text { population }\end{array}$ \\
\hline China & 1,4 billion & 244 thousand & 102 thousand & 13,1 & 42 & 0,017 \\
\hline Philippines & 105 million & 216 thousand & 73 thousand & 9,4 & 34 & 0,205 \\
\hline Indonesia & 264 million & 144 thousand & 51 thousand & 6,7 & 35 & 0,054 \\
\hline Russia & 144 million & 97 thousand & 48 thousand & 6,2 & 49 & 0,067 \\
\hline India & 1,3 billion & 86 thousand & 70 thousand & 9 & 81 & 0,006 \\
\hline Ukraine & 44 million & 69 thousand & 39 thousand & 5 & 57 & 0,156 \\
\hline
\end{tabular}

Source: compiled by the author on the basis of $[2,3,4]$

But the population of all above mentioned countries significantly exceeds the population of Ukraine. And if we take such an indicator as the share of jobs occupied by sailors in the population of these countries, then Ukraine will be in second place after the Philippines. By \% of officers among the total number of seamen, Ukraine came second only to India. Thus, every 20th officer of the merchant fleet in the world - from Ukraine. If we talk about the countries of Europe, then among them Ukraine is a leader.

BIMCO and ISF also publish information on the number of seamen in the world fleet, according to shipping companies. In this rating Ukraine is already fourth in China, the Philippines and Russia. Unfortunately, there is no statistics on the number of seamen in Ukraine. The only official data that can be used for some sort of orientation is the Seafarers' Training and Certification Inspection, which maintains a register of documents issued to seamen, and certificates giving the right to occupy certain positions in the fleet. According to the register in October 2017, such operating documents issued about 112 thousand [2].

There are about 450 crewing companies in Ukraine who are engaged in the supply of seamen abroad. Almost every major shipping company is guided by $5-10$ different countries from where seamen are recruited from its ship. It is believed that China overtook the Philippines as the largest source of supply for seamen qualified for international trade. Although the Philippines is still the largest source of supply to the private shipping fleet [2]. However, data from international shipping companies suggests that the use of Chinese seamen to service foreign ships may be limited; since the Philippines and Russia are seen as equally important sources of officers, while Ukraine and India are following them firmly.
During the last five years, the global supply of seamen has increased, and the number of qualified officers and ordinary people operating in the international merchant fleet continues to grow. It was reported that from 2005 to 2010 , the number of officers increased by $34 \%$, and now it is estimated to increase by $24 \%$ over the past five years. The total demand for seamen in 2015 was estimated at 1545000 seamen: about 790.5 thousand officers and 754.5 thousand ordinary. Demand for officials increased by about $24.1 \%$ from 2010 , while demand for ordinary people increased by about $1.0 \%$. The estimation of demand for officials and ordinary persons in 2015 as compared to the demand estimate presented in the previous reports is given in Table Estimated global demand for seafarers 2005-2015 [3]

Thus, if the expected demand for officials and ordinary people increased between 2005 and 2010 by $33.8 \%$ and $27.5 \%$, respectively, then the demand for officers continued, with only a slight increase in demand for ordinary people from 2010 year [3].

Estimates prepared for the 2015 report indicate that the current seamen global offer is about 1647500 seamen, of which approximately 774000 are officers and 873500 are seamen, and that the current world demand for seafarers is about 1545000 seamen, besides, the industry needs about 790.5 thousand officers and 754.5 thousand ordinary people. The current situation is as follows: a deficit of 16,500 officers and an excess of 119000 ordinary people, with a total surplus of 102500 seamen. This information is presented in the Table Current estimated global supply and demand of seafarers [3].

It is estimated that the level of employment and training of specialists over the past five years has increased. The basic forecast for the future supply and demand balance is calculated based on the information 
and data received for the 2015 report. It consists in the fact that the global supply of officers will steadily increase, but there will be a surging rising demand for officers. This is evidenced by data of the Tables Estimated supply-demand balance for officers [3].

The 2015 report indicates that the global merchant fleet is expected to grow in the next ten years, and demand for seamen is likely to continue to tend to general shortage offerings of officers. ICS and BIMCO predict that if the level of training is not significantly increased, the growth in demand for seamen could lead to a serious shortage of officers. Some officer categories are particularly scarce, in particular, engineers, managers, and officers for specialized ships such as chemicals, etc. The shortage of seamen will be observed despite the improvement in recruitment and training and the reduction in staffing levels over the past years. It should not be expected that there will be a lot of proposals from qualified and competent seamen in the future, even taking into account coordinated efforts and measures to address key human resource problems. It is important to promote a career in the sea, to strengthen maritime education and training all over the world, to address the conservation challenges of seamen and to continue to monitor the global supply and demand of seamen on a regular basis. Without continuing efforts to promote a career at sea and to improve recruitment and staffing, it is impossible to guarantee that a large number of skilled and competent seamen will be provided in the future. According to the report, over the past five years, the maritime industry has made significant progress in increasing recruitment and training and lowering the cost of officers (retaining skilled seamen and increasing the number of years they serve at sea) $[3,5,6$, $7,8]$.

Taking into account the presented analytical data it can be seen that the need for crewing services will continue to grow. The need to improve the quality of such services and improve the performance of these organizations (in particular, careful selection of personnel that meets the needs of the shipowner) is evident. Achievement of this goal will allow Ukrainian sailors to take advantage of their foreign counterparts when choosing shipowners for the required positions.

\section{Development of the optimization model}

Usually, the process of selecting a shipping crew by crewing companies specialists is carried out according to the algorithm of assessing candidates in the process of providing services by the crewing company and consists of the identification by means of modern specialized methods and technologies of a qualitative level of professional, qualification, personal characteristics, as well as motivational installations of the candidates that make up the pool. The purpose of the evaluation is to determine the numerical or descriptive values characteristics of the candidates. Candidates who constitute a pool should be evaluated using a single assessment system to obtain comparable results [9].
The selection of candidates is a professional activity, which represents the process of making a decision on the choice of certain applicants for employment in accordance with the existing staffing needs of the organization of the customer. The selection is carried out by comparing the results of the evaluation of individual candidates that make up the pool. The result of the selection is one or more candidates who will later be represented by the shipowner organizations who need personnel for employment [10]. If the seamen is successfully employed on the ship of the customer company, the crewing agent receives a remuneration from the shipowner or the occupant of the position. Most often, this is a certain amount paid for each month (or day) of the seamen's work on board, although there may also be a fixed remuneration, the size of which does not depend on the duration of the seamen's stay on board. Such payments may be paid for each contracted sailor, but some shipowners (usually in the oil and gas industry) are practicing a one-time payment for the selection of the specialist they require. Often this amount is calculated by computation the percentage of the wages of the employee they need. Accordingly, the more valuable and, accordingly, the highly paid specialist will find a recruiting firm, the greater will be the size of its remuneration [9]. It is known that the quality of services provided by crewing companies is reflected not only in the quality of satisfaction of the needs of the shipowner in the personnel, but also indirectly affects the operation of the shipping company as a whole.

In the absence of skilled personnel of the shipping company, great importance should be given to measures aimed at attracting, retaining the company and encouraging the development of a shipping crew, that is, measures of material and moral motivation. An additional method of material motivation can be the bonus system of pay, as well as the system of rewards sailor for excellent work. In practice, the main purpose of employment, as a rule, is the receipt of material remuneration. For a seaman, the highest possible earnings are associated with a number of negative non-material factors (long working day, bad working conditions, long separation from relatives, etc.). At the same time, work under such difficult conditions, besides high pay, can ensure the implementation of other competing goals (career development, professional experience, consolidation in a prestigious shipping company, etc.) [11]. Implementation of retraining and refresher training, as well as compensation of expenses for training and passing medical board, implementation of social guarantees for seamen, as well as carrying out measures to improve professional skills of recruitment managers, introduction of modern methods of testing seamen are unconditional factors of efficiency improvement functioning of the crewing company and strengthening its competitiveness among others [9].

Therefore, the task of optimizing the selection of crews by using the application of econometric and mathematical modeling remains very relevant.

As the basis for constructing an optimization model for the selection of crews of ships of maximum qualification, we will use the economic-mathematical model of the problem of appointment. We formulate the 
statement of the task of selecting the personnel of the maximum qualification for each position of the ship by the crewing company [12]. According to the analysis of the respective subscribed sites and its own database, the crewing company has selected a certain number of candidates for each of the vacant positions on the ships of the shipping companies. The positions are vacant or on the ships of companies with which the crewing company has an exclusive contract for servicing certain ships, or found on pre-paid sites. The selection is carried out according to the designated services of the customer - the shipping company - the parameters: the qualitative level of professional, qualification, personal characteristics, as well as the motivational units of candidates. For example, such as: specialty; age; necessary experience and work experience on certain ships; level of qualification (checked, in particular, on simulators); availability of certificates necessary for work; compliance of the sailor period of validity with the terms of the contract; compliance with health indicators; compliance with special documents, in particular subrogation, the ability to work in a particular region under the banner of a particular country, etc. These parameters determine the qualification characteristic $\mathrm{c}_{\mathrm{ijk}} i$-th candidate for $j$-th position on $k$-th ship. That is, the efficiency of the work of each specialist in the performance of a particular type of work on a particular ship is known $-c_{i j k}(i=1, \ldots, n ; j=1, \ldots, m ; k=1$, $\ldots, l$ ). Matrix of qualifying characteristics of $n$ candidates for $B_{j}$ position on $l$ ships $-C_{j}$ - presented in the table 2 .

Table 2. Matrix of qualification characteristics by $j$-th position, $C_{j}$.

\begin{tabular}{|c|c|c|c|c|c|}
\hline \multirow[t]{2}{*}{$\begin{array}{c}\text { Candidates for } j-t h \\
\text { position, } A_{i j}\end{array}$} & \multicolumn{4}{|c|}{$\begin{array}{c}\text { Ships with } \\
\text { vacancies for } j \text {-th } \\
\text { positions }\end{array}$} & \multirow[t]{2}{*}{$\begin{array}{c}\text { Number } \\
\text { candidates for } j \\
\text { th } \text { position, } a_{i j}\end{array}$} \\
\hline & $S_{j 1}$ & $S_{j 2}$ & $\ldots$ & $S_{j l}$ & \\
\hline$A_{1 j}$ & $c_{1 j 1}$ & $c_{1 j 2}$ & $\ldots$ & $c_{1 j l}$ & 1 \\
\hline$A_{2 j}$ & $c_{2 j 1}$ & $c_{2 j 2}$ & $\ldots$ & $c_{2 j l}$ & 1 \\
\hline$\ldots$ & $\ldots$ & $\ldots$ & $\ldots$ & $\ldots$ & $\ldots$ \\
\hline$A_{n j}$ & $c_{n j 1}$ & $c_{n j 2}$ & $\ldots$ & $c_{n j l}$ & 1 \\
\hline $\begin{array}{c}\text { Number of vacant } \\
\text { staffed posts per } j \text {-th } \\
\text { position on } k \text {-th } \text { ship, } \\
b_{j k}\end{array}$ & $b_{j 1}$ & $b_{j 2}$ & $\ldots$ & $b_{j l}$ & \\
\hline
\end{tabular}

Thus, $n$ candidates have been selected $A_{i j}$, who can and wish to take $j$-th vacant position $(i=1, \ldots, n ; j=1, \ldots, m)$.

Let the international seamen's market (in the market sector) have available vacancies at $j$-th position on $l$ ships of different shipowners, $k=1, \ldots, l$. The crewing agency either already cooperates with these shipowners or has the opportunity to start cooperation with them. Let's denote through $b_{j k}$ number of sailors, which is planned to be replaced $j$-th position on $k$-th ship. So, on $k$-th ship by $j$ th position are open $b_{j k}$ vacancies.

Assume that the crewing agency when sending one $i$ th candidate by $j$-th position on $k$-th ship receives income in size $d_{i j k}$ as a certain percentage of the seaman's salary amount $q_{i j k}$.

Matrix salaries of sailors at $j$-th position $Q_{j}$ presented in the table 3 .
Table 3. Matrix of salary on $j$-th position, $Q_{j}$.

\begin{tabular}{|c|c|c|c|c|}
\hline \multirow{2}{*}{ Candidates for $\boldsymbol{j}$-th position, $\boldsymbol{A}_{\boldsymbol{i j}}$} & \multicolumn{5}{|c|}{ Salary on $\boldsymbol{j}$-th positions } \\
\cline { 2 - 5 } & $\boldsymbol{S}_{\boldsymbol{j} \mathbf{1}}$ & $\boldsymbol{S}_{\boldsymbol{j} \mathbf{2}}$ & $\ldots$ & $\boldsymbol{S}_{\boldsymbol{j} \boldsymbol{l}}$ \\
\hline$A_{1 j}$ & $q_{1 j 1}$ & $q_{1 j 2}$ & $\ldots$ & $q_{1 j l}$ \\
\hline$A_{2 j}$ & $q_{2 j 1}$ & $q_{2 j 2}$ & $\ldots$ & $q_{2 j l}$ \\
\hline$\ldots$ & $\ldots$ & $\ldots$ & $\ldots$ & $\ldots$ \\
\hline$A_{n j}$ & $q_{n j 1}$ & $q_{n j 2}$ & $\ldots$ & $q_{n j l}$ \\
\hline
\end{tabular}

Each sailor can be sent for only one job. And for each position, the number of specialists may be assigned in accordance with the staffing schedule of the crew of the ship, which is determined by the shipping company.

It is necessary to appoint seamen-candidates for corresponding vacant positions on ships, so that the overall efficiency of all work is maximal. That is, it is necessary to entrust each candidate with the performance of one particular work on a particular ship in order to maximize the qualification of each position. The matrix of candidate nominations for $j$-th position $X_{j}$ presented in the table 4 .

Table 4. The matrix of assignments on $j$-th position, $X_{j}$.

\begin{tabular}{|c|c|c|c|c|c|}
\hline \multirow[t]{2}{*}{$\begin{array}{l}\text { Candidates for } j \text {-th } \\
\text { position, } A_{i j}\end{array}$} & \multicolumn{4}{|c|}{$\begin{array}{c}\text { Ships with } \\
\text { vacancies for } j \text {-th } \\
\text { positions } \\
\end{array}$} & \multirow[t]{2}{*}{$\begin{array}{c}\text { Number } \\
\text { candidates for } j- \\
t h \text { position, } a_{i j}\end{array}$} \\
\hline & $S_{j 1}$ & $S_{j 2}$ & $\ldots$ & $S_{j l}$ & \\
\hline$A_{1 j}$ & $x_{1 j 1}$ & $x_{1 j 2}$ & $\ldots$ & $x_{1 j l}$ & 1 \\
\hline$A_{2 j}$ & $x_{2 j 1}$ & $x_{2 j 2}$ & $\ldots$ & $x_{2 j l}$ & 1 \\
\hline$\ldots$ & $\ldots$ & $\ldots$ & $\ldots$ & $\ldots$ & $\ldots$ \\
\hline$A_{n j}$ & $x_{n j 1}$ & $x_{n j 2}$ & $\ldots$ & $x_{n j l}$ & 1 \\
\hline $\begin{array}{c}\text { Number of vacant } \\
\text { staffed posts per } j \text {-th } \\
\text { position on } k \text {-th } \text { ship, } \\
b_{j k}\end{array}$ & $b_{j 1}$ & $b_{j 2}$ & $\ldots$ & $b_{j l}$ & \\
\hline
\end{tabular}

This is a statement of the classical task of appointment.

Let's make an economic-mathematical model of the task.

Let's denote through $x_{i j k}$ - fact of appointment $i$-th candidate on $j$-th position on $k$-th ship.

We will assume that:

$$
x_{i j k}=\left\{\begin{array}{c}
1, \text { if } i-t h \text { candidate is appointed } \\
\text { on } j-t h \text { position on } k-t h \text { ship } ; \\
0, \quad \text { if } i-t h \text { candidate is not appointed } \\
\text { on } j-t h \text { position on } k-t h \text { ship. }
\end{array}\right.
$$

Output parameters of the task of optimization of selection of frames of crews of ships:

$n$ - number of candidates for $j$-th position;

$m$ - number of positions;

$a_{i j}=1$ - unit amount of resource: the candidate $A_{i}$ can only be assigned to one $j$-th position;

$b_{j k}=t-$ number of vacant staffed positions per position $B_{j}$ on $k$-th ship;

$s_{j k}=l$ - number of ships $S_{k}$, where vacant position $B_{j}$;

$c_{i j k}$ - qualification characteristic of the candidate $A_{i}$ for performance of work on the position $B_{j}$ on $k$-th ship;

$x_{i j k}$ - fact of appointment or non-appointment of a candidate $A_{i}$ on the position $B_{j}$ on $k$-th ship; 
$Z_{j}$ - general (total) quality characteristics of the distribution of candidates for $j$-th position;

$Z$ - general (total) quality characteristics of the distribution of candidates for all positions.

$D_{j}$ - income earned by the crewing company as \% of the wages of candidates assigned to $j$-th position;

$D$ - income received by the crewing company as $\%$ of the salary of candidates appointed for all positions.

The task is to find the distribution $X_{j}=\left(x_{i j k}\right)$ sailors on ships for each $j$-th position (that is, to find a matrix of appointments), which maximizes the target function:

$$
Z_{j}=Z_{j}\left(X_{j}\right)=\sum_{i=1}^{n} \sum_{k=1}^{l} c_{i j k} * x_{i j k} \rightarrow \max
$$

for limitations:

$$
\left\{\begin{array}{c}
\sum_{k=1}^{l} x_{i j k}=1, \quad i=\overline{1 ; n} \\
\sum_{i=1}^{n} x_{i j k}=b_{j k}, \quad k=\overline{1 ; l .}
\end{array}\right.
$$

and

$$
x_{i j k}=\left\{\begin{array}{c}
1, \text { if } i-t h \text { candidate is appointed } \\
\text { on } j-t h \text { position on } k-t h \text { ship } \\
0, \text { if } i-t h \text { candidate is not appointed } \\
\text { on } j-t h \text { position on } k-t h \text { ship. }
\end{array}\right.
$$

Thus, the economic-mathematical model of selection of personnel of the maximum qualification for each position of crews of ships is represented by formulas (1) $-(3)$.

The more highly-paid personnel will pick up the crewing company, the higher its income.

Next we will find the income received by the company as $\%$ of the wages of the candidates assigned to $j$-th position. Let it be fixed for today, $\%-10 \%$.

$$
D_{j}=0.1 \sum_{i=1}^{n} \sum_{k=1}^{l} q_{i j k} * x_{i j k}
$$

That is, the income of the crewing from the main activity will be:

$$
D=\sum_{j=1}^{m} D_{j}
$$

In order to find the profit of a crewing company, it is necessary to deduct from the income constant $V_{\text {const }}$ and variables $V_{\text {var }}$ costs.

How variable costs $V_{\text {var }}$ we consider the costs of crewing to verify the legitimacy of documents seamen (work diplomas), selected for a position on a particular ship. The fixed pay for such a service, such as checking the legitimacy of documents, today amounts to UAH 150 per person.

$$
V_{v a r}=150 * \sum_{j=1}^{m} \sum_{i=1}^{n} \sum_{k=1}^{l} x_{i j k}
$$

The following costs are incurred for permanent creeping expenses: support for a database template, site maintenance, office rental, utility payments, salary of office workers, certification of crewing, taxes, etc.).

Consequently, we obtain a formula for finding income from the main activity of crewing.

$$
\mathrm{P}=\mathrm{D}-\mathrm{V}_{\mathrm{var}}-\mathrm{V}_{\text {const }}
$$

With the help of constructed economic-mathematical

\begin{tabular}{|c|c|c|c|c|c|}
\hline \multirow[t]{2}{*}{$\begin{array}{c}\text { Candidates for } j=1 \\
\text { position, } A_{i 1}\end{array}$} & \multicolumn{4}{|c|}{$\begin{array}{c}\text { Ships with vacancies } \\
\text { for } j=1 \text { Captain's } \\
\text { position }\end{array}$} & \multirow{2}{*}{$\begin{array}{c}\text { Number } \\
\text { candidates for } \\
j=1 \text { position, } \\
a_{i 1}\end{array}$} \\
\hline & $S_{11}$ & $S_{12}$ & $S_{13}$ & $S_{11}$ & \\
\hline$A_{11}$ & 0.75 & 0.9 & 0.8 & 0.75 & 1 \\
\hline$A_{21}$ & 0.82 & 0.69 & 0.93 & 0.82 & 1 \\
\hline$A_{31}$ & 0.94 & 0.78 & 0.85 & 0.94 & 1 \\
\hline$A_{41}$ & 0.76 & 0.92 & 0.88 & 0.76 & 1 \\
\hline $\begin{array}{c}\text { Number of vacant } \\
\text { staffed posts per } \\
j=1 \text { position on } k \text {-th } \\
\text { ship, } b_{1 k} \\
\end{array}$ & 1 & 1 & 1 & 1 & \\
\hline
\end{tabular}
model of selection of personnel of the maximum qualification, we will make a selection of captains for the crewing company "Alfa crewing". Let assembled to construct a model of choice of captains $(j=1)$ information is presented tablotically (Table 5-7).

Table 5. Matrix of qualification characteristics by $j=1$ Captain's position, $C_{1}$.

Table 6. Matrix of salary on $j=1$ Captain's position, $Q_{1}$.

\begin{tabular}{|c|c|c|c|c|}
\hline \multirow{2}{*}{$\begin{array}{c}\text { Candidates for } \boldsymbol{j}=\mathbf{1} \\
\text { position, } \boldsymbol{A}_{\boldsymbol{i} 1}\end{array}$} & \multicolumn{4}{|c|}{$\begin{array}{c}\text { Salary of the captain on the ships, } \\
\text { thousands of dollars }\end{array}$} \\
\cline { 2 - 5 } & $S_{11}$ & $S_{12}$ & $S_{13}$ & $S_{11}$ \\
\hline$A_{11}$ & 8.1 & 9.3 & 8.6 & 8.1 \\
\hline$A_{21}$ & 8.8 & 8 & 9.5 & 8.8 \\
\hline$A_{31}$ & 9.6 & 8.4 & 9.1 & 9.6 \\
\hline$A_{41}$ & 8.2 & 9.4 & 9.2 & 8.2 \\
\hline
\end{tabular}

Table 7. The matrix of assignments on $j=1$ Captain's position, $X_{1}$.

\begin{tabular}{|c|c|c|c|c|c|}
\hline \multirow{2}{*}{$\begin{array}{c}\text { Candidates for } \boldsymbol{j}=\mathbf{1} \\
\text { position, } \boldsymbol{A}_{\boldsymbol{i} 1}\end{array}$} & \multicolumn{3}{|c|}{$\begin{array}{c}\text { Ships with vacancies } \\
\text { for } \boldsymbol{j}=\mathbf{1} \text { Captain's } \\
\text { position }\end{array}$} & $\begin{array}{c}\text { Number } \\
\text { candidates for } \\
\text { i=1 position, } \boldsymbol{a}_{\boldsymbol{i 1}}\end{array}$ \\
\cline { 2 - 6 } & $S_{11}$ & $S_{12}$ & $S_{13}$ & $S_{11}$ & \\
\hline$A_{11}$ & $x_{111}$ & $x_{112}$ & $x_{113}$ & $x_{111}$ & 1 \\
\hline$A_{21}$ & $x_{211}$ & $x_{212}$ & $x_{213}$ & $x_{211}$ & 1 \\
\hline$A_{31}$ & $x_{311}$ & $x_{312}$ & $x_{313}$ & $x_{311}$ & 1 \\
\hline$A_{41}$ & $x_{411}$ & $x_{412}$ & $x_{413}$ & $x_{411}$ & 1 \\
\hline $\begin{array}{c}\text { Number of vacant } \\
\text { staffed posts per } \boldsymbol{j}=\mathbf{1} \\
\text { position on } \boldsymbol{k} \text { - } \boldsymbol{t} \boldsymbol{h} \\
\text { ship, } \boldsymbol{b}_{\mathbf{k} \boldsymbol{k}}\end{array}$ & 1 & 1 & 1 & 1 & \\
\hline
\end{tabular}

The economic-mathematical model of selection of captains of the maximum qualification is represented by the formulas 8-10:

$$
Z_{1}=Z_{1}\left(X_{1}\right)=\sum_{i=1}^{4} \sum_{k=1}^{3} c_{i 1 k} * x_{i 1 k} \rightarrow \max
$$

for limitations:

$$
\left\{\begin{array}{l}
\sum_{k=1}^{3} x_{11 k} \leq 1, \\
\sum_{k=1}^{3} x_{21 k} \leq 1, \\
\sum_{k=1}^{3} x_{31 k} \leq 1, \\
\sum_{k=1}^{3} x_{41 k} \leq 1, \\
\sum_{i=1}^{4} x_{i 11}=1, \\
\sum_{i=1}^{4} x_{i 12}=1, \\
\sum_{i=1}^{4} x_{i 13}=1 .
\end{array}\right.
$$


and

$$
x_{i j k}=\left\{\begin{array}{c}
1, \text { if } i-t h \text { candidate is appointed } \\
\text { on } j=1 \text { position on } k-t h \text { ship } \\
0, \text { if } i-t h \text { candidate is not appointed } \\
\text { on } j=1 \text { position on } k-t h \text { ship. }
\end{array}\right.
$$

The results of implementing the model in the Excel environment are shown in the figure 1.

Therefore, in order for the overall qualification of candidates for the position of the captain to be maximal, they should be assigned as follows: will receive the appointment of Captains 2, 3 and 4 candidates; 1 candidate will not receive a job this time; all vessels, on which the vacant position of the captain was, will be provided by the performers of work (J3-J6). In addition, the profit of the crewing company will be 2.85 thousand dollars (H8).

Similarly, it is possible to distribute candidates for all vacant positions of crews of vessels. Therefore, crewing company "Alfa crewing" it is expedient to apply economic-mathematical modeling for management of selection of personnel in order to maximize the overall qualification characteristic. The use of such a toolkit allows you to determine who and on what ship to appoint to one or another position in order to maximize profitability.

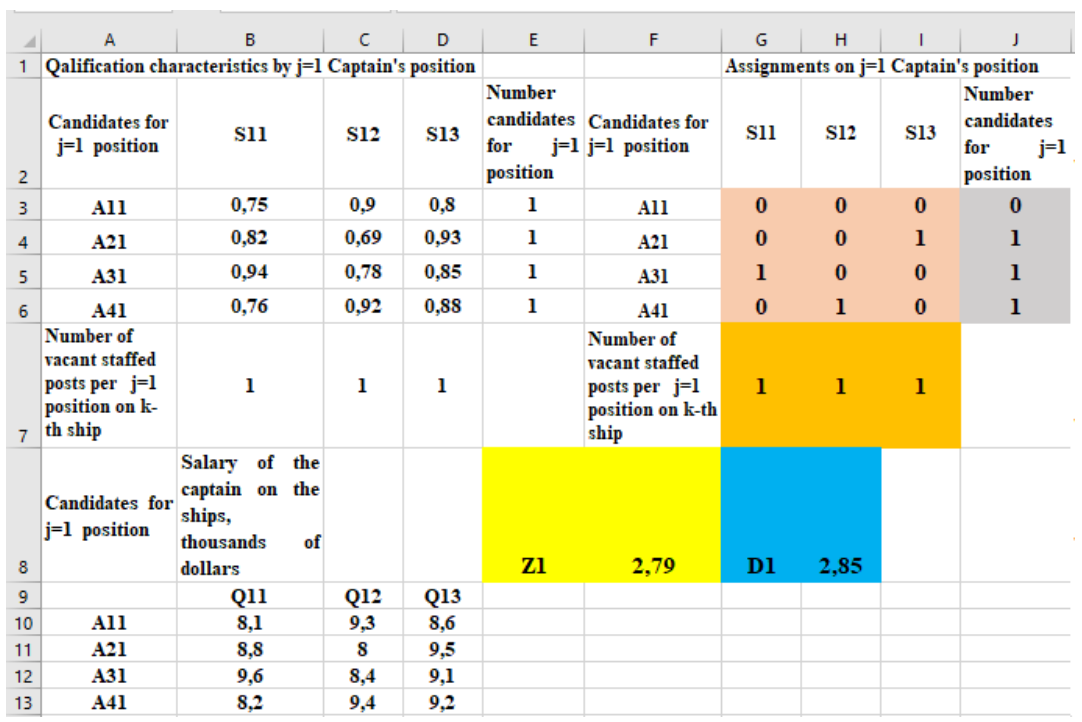

Fig. 1. The result of the selection of personnel of the maximum qualification for position of captain

\section{Resulting and conclusions}

Thus, we can formulate conclusions about the conducted research. The model of optimization of the selection process for crews of ships can be applied for distribution of personnel to ship of any categories, including bulk carriers, tankers, container carriers, etc.

The model can be applied to create on its basis models of decision support systems.

The results of the study can be used by the managers of crewing companies, managers and employees of the services of work with the personnel of shipping companies.

The practical significance of the study is that the use by the crewing companies of the proposed recommendations for the application of methods of economic and mathematical modeling for the selection of skilled personnel for each position will increase the efficiency of the organization of the work of the crew of ships, as well as optimize the income of the crewing company. Optimization not only increases the efficiency of the crewing company, but also increases its responsibility. After all, the quality of services provided by crewing companies reflects not only the quality of meeting the needs of shipping companies in the personnel, but also affects both the quality of service provided by shipping companies and the efficiency of the operation of shipping companies in general.

\section{References}

1. Prylypko, O.: Natsionalnyi kriuinh: vid siroho do biloho (National crewing: from Gray to White). https://day.kyiv.ua/uk/article/ekonomika/nacionalny y-kryuying-vid-sirogo-do-bilogo (2015). Accessed $20 \mathrm{Feb} 2019$

2. Miyusov, M.: Perspektivy podgotovki i trudoustroystva moryakov (Prospects for training and employment of seafarers). https://ports.com.ua/articles/perspektivypodgotovki-i-trudoustroystva-moryakov Accessed 22 Feb 2019

3. International Chamber of Shipping: MANPOWER REPORT: The global supply and demand for seafarers in 2015. http://www.icsshipping.org/docs/default-source/resources/safetysecurity-and-operations/manpower-report-2015executive-summary.pdf (2018). Accessed 22 Feb 2019

4. Ilnitskiy, K.: Ukraina zanyala shestoye mesto sredi stran-postavshchikov moryakov (Ukraine ranked sixth among the countries-suppliers of sailors). 
https://ports.com.ua/articles/ukraina-zanyalashestoe-mesto-sredi-stran-postavshchikov-moryakov (2018). Accessed 25 Feb 2019

5. International Chamber of Shipping: Annual-review2018. http://www.ics-shipping.org/docs/defaultsource/resources/annual-review-2018.pdf?sfvrsn=14 (2018). Accessed 25 Feb 2019

6. International Chamber of Shipping: Annual-review2017. http://www.ics-shipping.org/docs/defaultsource/resources/annual-review-2017.pdf?sfvrsn=14 (2017). Accessed 25 Feb 2019

7. SAFETY4SEA: Global supply and demand for seafarers. https://safety4sea.com/global-supplydemand-seafarers-2/ (2018). Accessed 25 Feb 2019

8. SAFETY4SEA: New report predicts potential shortage of almost 150,000 officers by 2025 . http://safety4sea.com/new-report-predicts-potentialshortage-of-almost-150000-officers-by-2025/ (2016). Accessed 25 Feb 2019

9. Yatsenko, M.S., Honcharova, I.O.: Aktualni problemy udoskonalennia yakosti kriuinhovykh posluh (Actual problems of quality improvement of crewing services). Economics: time realities. 1(29), 162-170 (2017)

10. Pasyuk, E.D., Ivanova, S.E.: Teoreticheskiye aspekty razvitiya rynka uslug, predostavlyayemykh kryuingovymi kompaniyami (Theoretical aspects of the development of the market of services provided by crewing companies). http://jurnal.org/articles/2007/ekon56.html (2007). Accessed 25 Feb 2019

11. Lukashevich, V.M.: Opredeleniye sushchnosti kontseptualnykh podkhodov $\mathrm{k}$ vedeniyu kryuingovogo biznesa (Determination of the essence of conceptual approaches to the management of crewing business). Technology audit and production reserves. 5(2(19)), 43-47 (2014)

12. Ivashko, L.M., Bondarenko, Yu.M.: Optymizatsiia protsesu pidboru kadriv ekipazhiv suden (Optimization of the process of selection of frames of crews of vessels). Paper presented at the international conference on the socially-competent management of corporations in a behavioral economy, Lesya Ukrainka Eastern European National University, Lutsk, 4-9 November 2018 